\title{
Pengaruh Ukuran Butir (grain size) pada pembuatan Bonded Magnet NdFeB
}

\author{
Arjuna Ritawanti ${ }^{1}$, Kerista Sembiring $^{1}$ Muljadi $^{2}$, Erfin Yundra Febrianto ${ }^{2}$ \\ ${ }^{1}$ Fisika,MIPA,Universitas Sumatera Utara, \\ ${ }^{2}$ Pusat Penelitian Fisika - LIPI, Puspiptek,Serpong \\ Email : muljadi2002@yahoo.com
}

\begin{abstract}
ABSTRAK
Telah dilakukan penelitian tentang pembuatan magnet permanen bonded NdFeB dengan polimer bakelit dilakukan dengan mencampurkan serbuk magnet Neodymiun Iron Boron (NdFeB) komersil tipe MQP-B ${ }^{+}$dengan perekat menggunakan cetakan (moulding). Sebelum serbuk NdFeB di campur dilakukan pengayakan terhadap kedua serbuk .Komposisi bakelit sebesar 0, 2,5\%, 5\% dan 7,5\% berat dari massa total sampel 8 gram. Campuran ini kemudian dicetak dengan metode dry compression moulding dengan tekanan sampel 5 tonforce/ $\mathrm{cm}^{2}$ demgan menggunakan suhu hot press sebesar $120^{\circ} \mathrm{C}, 140^{\circ} \mathrm{C}, 160^{\circ} \mathrm{C}$ dan $180^{\circ} \mathrm{C}$ selama 30 menit.Disini untuk mengetahui pengaruh grain size di lakukan pengayakan dalam serbuk dalam ukuran 100 Mesh dan 200 Mesh. Setelah di dapatkan hasil sampel dalam bentuk pelet di simpan dalam ruang vakum Desicator untuk menghindari dari pengaruh oksidasi.Uji fisis dilakukan dalam penelitian ini dengan mengukur Bulk density dan melihat mikrostrukur dengan menggunakan SEM.Selanjutnya uji magnetisasi dilakukan untuk mengetahui sifat magnet yang terbaik dan karakterisasi magnet dilakukan magnet dilakukan dengan mengunakan Permagraph $C$ untuk mengetahui nilai induksi remanensi $(\mathrm{Br})$ dalam suatu medan magnet, koersivitas (Hc) dăn Energi Produksi Maksimum $(\mathrm{BH})_{\max }$. Hasil penelitian di peroleh sifat magnet yang terbaik pada ukuran 100 Mesh Bakelit 2,5\% wt pada suhu Hot press $160{ }^{\circ} \mathrm{C}$ menghasitkan nilai kuat magnet 1.633 Gauss, $\mathrm{Br}=3,72 \mathrm{kG}, \mathrm{Hci}=7,557 \mathrm{KOe}$ dan $\mathrm{BH}_{\max }=2,85$ MGQe.

Key word
\end{abstract}

\section{PENDAHULUAN}

Magnet adalah suatu materi yang hempunyai suatu medan magnet.Magnet juga menupakan material maju yang sangat penting untuk beragam aplikas teknologi canggih, berfúngsi sebagai komponen pengubah energi gerak menjadi Histrik dan sebaliknya, seperti otomotif, elektronik dan-energ (Collocott, S.J., 2007).

Setiap magnet memiliki dua kutub, yaitu utara dan selatan. Kutub magnet adalah daerah ýang berada pada ujung-ujung magnet dengan kekuatan magnet yang paling besar berada pada kutub kutubnya. Magnet dapat menarik benda lain, beberapa benda bahkan tertarik lebih kuat dari yang lain, yaitu bahan logam. Namun tidak semua logam mempunyai daya tarik yang sama terhadap magnet. Besi dan baja adalah dua contoh materi yang mempunyai daya tarik yang tinggi oleh magnet.[1].

Material magnetik dibedakan menjadi dua macam berdasarkan kekuatan medan koersivitasnya yaitu material magnet lunak dan material magnet keras.Material magnet lunak memiliki medan koersivitasnya yang kuat.Magnet lunak mudah dimagnetisasi serta mudah pula mengalami demagnetisasi.Spesifikasi yang agak kritis untuk magnet lunak adalah induksi magnet B jenuh (tinggi),medan koersif (rendah) dan permeabilitas maksimum (tinggi).Permeabilitas ditandai dengan rasio $\mathrm{B} / \mathrm{H}$ tidak linear yang berarti magnetisasi mudah terjadi karena diperlukan medan magnetik kecil untuk menghasilkan rapat fluks yang tinggi (induksi) Sementara jumlah induksi tergantung pada medan magnet dan jenis bahan.[ 2].Pada magnep Keras baik induksi remanen (rapat fluks) dan medan koersif, $\mathrm{Br}$ dan Hc masing- masing besar untukmagnet keras. Hasil perkalian merupakan patokanuntuk energi demagnetisasi.

3 Perkembangan magnet permanen saat ini sangat difokuskan untuk magnet permanen energi tinggi. Salah satu bahan magnet permanenyăngdapatmenghasilkan energi tinggi tersebut adalah dari jenis Nd-Fe-B .Bahkan magnet permanen berbasis $\mathrm{Nd}-\mathrm{Fe}-\mathrm{B}$ telah menghasilkan energi produk mencapai 50 MGOe. Magnet permanen berjenis $\mathrm{Nd}-\mathrm{Fe}-\mathrm{B}$ ini terbuat dari paduan logam tanah jarang berjenis Neodymiumlogam Besi, dan Boron dengan fasa magnet $\mathrm{Nd}_{2} \mathrm{Fe}_{14} \mathrm{~B}$ yang memiliki struktur kristal tetragonal. Kelebihan lain dari magnet permanen berbasis ini adalah memiliki Induksi magnet saturasi yang tinggi mencapai 1,6 $\mathrm{T}$ atau $16 \mathrm{kG}$, dengan induksi remanensi tertinggi saat ini mencapai $1,53 \mathrm{~T}$ atau $15,3 \mathrm{kG}$

Polimer (makromolekul) adalah kumpulan molekul-molekul yang berikatan secara kovalen yang sangat panjang yang dapat dihasilkan dari sumber alami atau sintetik. Contoh misalnya polimer bakelit (fenol formaldehide) merupakan senyawa penyusun makro melekul yang berulang merupakan polimer sintesis yaitu polimer yang dibuat dari pabrik.Selain itu bakelit merupakan polimer termoset yang mempunyai sifat tidak dapat melunak dan dibentuk ulang,Jika dipanaskan pada suhu tinggi,maka plastik ini akan terurai dan rusak. 
Proses pembentukan bakelit adalah polimer kondensasi yang merupakan reaksi penggabungan monomer-monomer dengan melepas molekul kecil seperti $\mathrm{H}_{2} \mathrm{O}$ dan $\mathrm{CH}_{3} \mathrm{OH}$.Bakelit digunakan untuk instalasi listrik dan alat-alat yang tahan suhu tinggi misalnya asbak dan fitting lampu listrik [4]

Aplikasi untuk polimer bonded magnet menjadi semakin penting dalam kehidupan kita sehari-hari misalnya dalam berbagai perangkat elektronik, otomatisasi peralatan kantor, otomotif, komponen dan peralatan rumah, seperti komputer hard disk drive (HDD). Dewasa ini penggunaan magnet memiliki kepentingan besar hal ini dilihat dengan perkembangan kebutuhan yang semakin meningkat, misalnya saat ini mobil memiliki beberapa ratus magnet yang digunakan pada alat sensornya,elektronik dan peralatan kantor.[5] Metode Hot Press digunakan untuk melihat jenis bahan baku dari sifat magnetik $\mathrm{Br}$, He dan $(\mathrm{BH})_{\max }$ maka serbuk MQP-B ${ }^{+}$yang lebih baik şifat magnetiknya[6]

Parameter perlu di Press dan Pematangan (Aging) biar terjadi pemadatan dan dapat merubah kisi-kisi dari kristal parameter proses Aging mempengaruhi kondisi magnet ,aging vakum lebih bagus daripada aging di uda dari sifat magnetnya.Parameter fanpa Aging hasilnya memang bagus tapi magnetnya mudah rapuh.[7]

Pada penelitian ini kita akan membahas pengaruh ukuran butir pada permbuatan bonded magnet $\mathrm{NdFeB}$ untuk memperoteh sifat magnet yang baik.

\section{METODOLOGI}

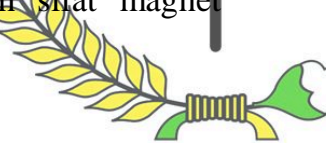

Alat yang digunakan dalam penelitian ini adalah ayakan 100 mesh dan 200 mesh, neraca digital 4 digit, spatula, gelas ukur pyrex ukuran150ml,cetakan(moulding), jangka sorong dan amplas.Untuk karakterisasi sampel dipakai uji fisis yaitu uji bulk density dan Scanning electron Microscope (SEM) untuk mengetahui strukturmikro sampel. Impulse Magnetizer $k$-series MagnetPhysik Dr.Steingroever $\mathrm{GmbH}$ digunakan untuk magnetisasi sampel yang telah dicetak dan untuk mengukur kuat magnet menggunakan gaussmeter dan karakterisasi sifat magnet dengan Permeagraph.

Bahan yang digunakan serbukmagnet Neodymium Iron Boron ( $\mathrm{NdFeB}$ ) komersil type MQP-B $^{+}\left(\rho=7,6 \mathrm{gr} / \mathrm{cm}^{3}\right)$ berfungsi sebagai bahan baku yang digunakan untuk membuat magnet bonded dan polimer Bakelit $\left(\rho=1,36 \mathrm{~g} \mathrm{r} / \mathrm{cm}^{3}\right)$ berfungsi sebagai bahan perekat polimer yang bersifat termoset.

\section{Persiapan bahan dasar}

Melakukan pengayakan terhadap kedua serbuk dalam ukuran 100 Mesh dan 200 Mesh.Bahan yang diayak di buat dalam 3 variasi sampel sebanyak 8 gram.Perbandingan komposis antara serbuk $\mathrm{NdFeB}$ : Bakelit adalah $100 \%$ wt : $0 \%$ wt; $97,5 \%$ wt :2,5\%wt, $95 \%$ wt:5\%wt dan 92,5\%wt : 7,5\%wt.

\section{Proses pembentukan}

Dilakukan dengan memasukkan bahan serbuk kedalam cetakan (Moulding) agar serbuk membentuk green body yang sesuai bentuk cetakan yang diinginkan.kemudian dilakukan kompaksi dengan tekanan 5 tonforce/ $\mathrm{cm}^{2}$ dengan waktu penahanan (holding time) 30 menit dengan variasi suhu hot press $120^{\circ} \mathrm{C}, 140^{\circ} \mathrm{C}, 160^{\circ} \mathrm{C}$ dan $180^{\circ} \mathrm{C}$. Waktu penahanan 30 menit berguna untuk penyempurnaan pembakakaran pada saat kompaksi menghilangkan udara yang terjebak (pori) sehingga pada waktu ditahan 30 menit maka akan ada oksida atau bahan pengotor yang dibuang pada saat holding time 30 menit dan karena bakelit $\left(\mathrm{C}_{2} \mathrm{H}_{5} \mathrm{OH}\right)$ memiliki kandungan air $\mathrm{OH}$ sehingga terbuang pada saat pemanasan.

Karakterisasi bulk density dengan mengukur diameter dan tinggi sampel dengan jangka sorong untuk mendapatkan volume dari sampel dan menimbang setiap sampel dengan neracâ digital.Setelah itu dilakukan proses magnetisasi yáitu memberikan medan magnet luar agar memiliki medan magnet sendiri atau permaneh.Perlu diketahui bahwa pada saat bahan magnet tembentuk menjadi kristal itu belum memifikrcdaya tarik terhadap logam. Setelah diberi magnet Juar bahan baru akan memiliki magnet sendir.Proses - -1 magnetisai dilakukan dengan menggunakan alat Magnet-Physic Dr.Steingroever GmbH Impulse magnetizer $\mathrm{K}$ series dengan $\mathrm{V}=$ 1500 volt dan I sekitar 5,15 - 5,21 kA).kemudian setelah memilki magnet sendiri diukur kuat magnet (fluks D magnet) dengan menggunakan gaussmeter.Dari hasil gaussmeter yang diperoleh kita dapat mengetahui sampel yang baik dilakukan analisis mkrostruktur denagn menggunakan Scanning Electron Mikrostruktur (SEM).Setelah itu dilakukan karakterisasi magnet.

\section{HASIL DAN PEMBAHASAN Sifat fisis}

Pengukuran densitas untuk $\mathrm{NdFeB}$ dengan variasi komposisi 2,5\%;5\% dan 7,5\% untuk ukuran 100 Mesh dengan menggunakan persamaan $\rho=\frac{m}{v}$ dengan $\rho$ adalah bulk density,m massa sampel dan $\mathrm{v}$ volume sampel.Dari hasil perhitungan diperoleh nilai bulk density sebagai berikut : 


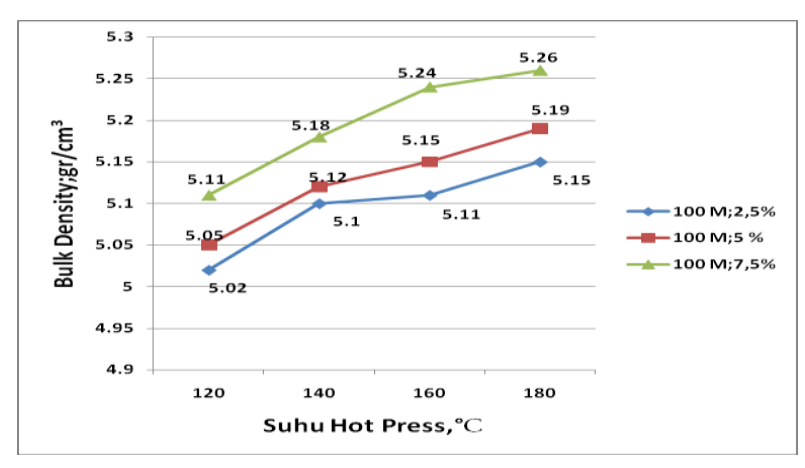

Gambar 1. Grafik hubungan antara variasi komposisi bakelit dengan Bulk Density terhadap suhu hot press $120^{\circ} \mathrm{C}, 140^{\circ} \mathrm{C}, 160^{\circ} \mathrm{C}$ dan $180^{\circ} \mathrm{C}$.

\section{Sifat Magnet}

Hasil pengujian sifat magnet pada penelitian ini adalah pengujian kerapatan fluks magnet dengan menggunakan gaussmeter.Kerapatan fluks magnetik menunjukkan tingkat kerapatan momenmomen magnet yang terdapat dalam suatu material magnet.Semakin banyak momen-momen magnet yang terdapat dalam suatu material mengakibatkan nilai kerapatan fluks magnetnya meningkat setelah terjadi magnetisasi.

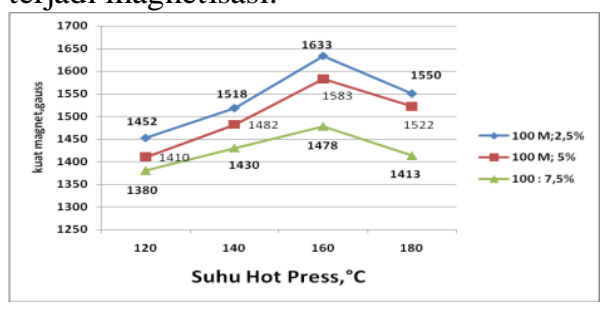

Dari grafik 1,menunjukan semakin banyak penambahan komposisi bakelit nilai bulk density semakin bertambah (mengalami kenaikan) di karenakan dikompaksi dengan suhu hot press pada suhu $120^{\circ} \mathrm{C}, 140^{\circ} \mathrm{C}, 160^{\circ} \mathrm{C}$ dan $180^{\circ} \mathrm{C}$. Pada saat kompaksi terjadi pemadatan dimana merupảkan suatu proses dimana udara pada pori-pori tanah dikeluarkan dengan suatu cara mekkanis. Pada proses kompaksi untuk setiap daya pemadatan tertentu,pemadatan yang tercapai tergantung pada kadar air material.Material yang memiliki kadar ai rendah akan lebih sulit dipadatkan dibandkingkan yang memiliki kadar air yang tinggi.

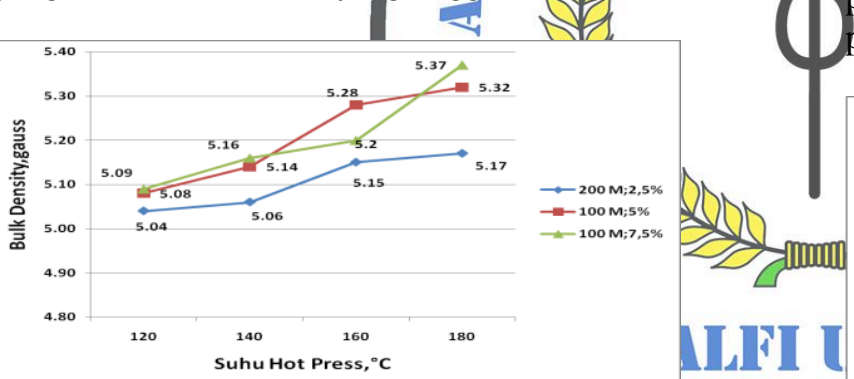

Gambar 1. Grafik hubungan antara variasi komposisi bakelit dengan Bulk Density terhadap suhu hot press $120^{\circ} \boldsymbol{C}, 140^{\circ} \mathrm{C}, 160^{\circ} \mathrm{C}$ dan $180^{\circ} \mathrm{C}$

Dari grafik 2,menunjukan semakin banyak penambahan komposisi bakelit.Nilai bulk density semakin bertambah (mengalami kenaikan) di karenakan dikompaksi dengan pada suhu $120^{\circ} \mathrm{C}$, $140^{\circ} \mathrm{C}, 160^{\circ} \mathrm{C}$ dan $180^{\circ} \mathrm{C}$. Kemudian kalau dibandingkan gambar 1 dan gambar 2 ,semakin halus ukuran serbuk sangat mempengaruhi besarnya bulk density juga dipengaruhi porositas dari serbuk dan kemurnian bahan.Semakin kecil porositas , bulk densitymengalami kenaikan.Porositas dari ukuran serbuk 200 Mesh lebih kecil daripada ukuran 100 Mesh,ukuran serbuk 200 Mesh lebih pada dari ukuran 100 Mesh.Bulk density naik sesuai dngan kenaikan suhu dan ukuran dari butir dari serbuk.
Gambar 3 Kuat Medan Magnet ukuran 100 Mesh terhadap suhu Hot Press

UNIVI Pada gambar 3 ditunjukkan bahwa kuat magnet 4 pada komposisi $97,5 \%$ wtNdFeB : $2,5 \%$ wtbakelit "pada setiap suhu $120^{\circ} \mathrm{C}, 140^{\circ} \mathrm{C}$ dan $160^{\circ} \mathrm{C}$ mengalami kenaikan tetapi pada suhu $180^{\circ} \mathrm{C}$ kuat magnetnya mengalami penurunan.Begitu juga pada komposisi 95\% NdFeB : $5 \%$ wt bakelit pada setiap kenaikan suhu $120^{\circ} \mathrm{C}, 140^{\circ} \mathrm{C}$ dan $160^{\circ} \mathrm{C}$ serta pada kompesisi92,5\% 5 dFeB : 7,5\% bakelit,tetapi pada suhu $080^{\circ} \mathrm{C}$ kuat magnetnya mengalami penurunan.

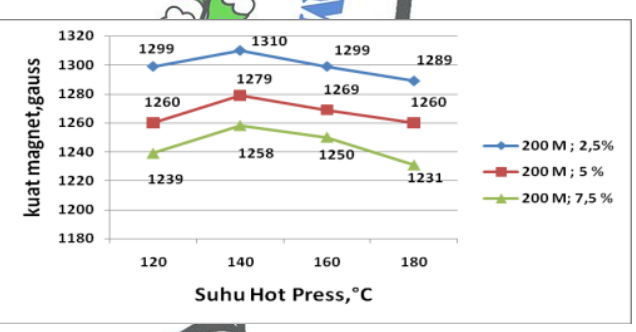

Gambar 4 Kuat Medan Magnet ukuran 200 Mesh terhadap suhu Hot Press magnet pada komposisi 97,5\% wtNdFeB:2,5\%wtbakelit pada setiap suhu $120^{\circ} \mathrm{C}, 140^{\circ} \mathrm{C}$ dan $160^{\circ} \mathrm{C}$ mengalami kenaikan tetapi pada suhu $180^{\circ} \mathrm{C}$ kuat magnetnya mengalami penurunan.Begitu juga pada komposisi 95\%wt $\mathrm{NdFeB}: 5 \%$ wt bakelit pada setiap kenaikan suhu $120^{\circ} \mathrm{C}, 140^{\circ} \mathrm{C}$ serta pada komposisi $92,5 \% \mathrm{NdFeB}$ : $7,5 \%$ bakelit,tetapi pada suhu $160^{\circ} \mathrm{C}$ dan $180^{\circ} \mathrm{C}$ kuat magnetnya mengalami penurunan karena dipengaruhi ukuran serbuk.

Dari gambar a dan b diambil perbandingan bahwa ukuran serbuk sangat mempengaruhi kuat magnet yang ada hubungannnya dengan sifat magnet.Untuk mencari sifat magnet yang baik tidak perlu lagi lagi memakai serbuk yang lebih halus cukup untuk 100 Mesh.Maka sifat magnet yang baik pada komposisi $97,5 \% \mathrm{NdFeB}$ : 2,5\%bakelit pada suhu $160^{\circ} \mathrm{C}$ pada ukuran serbuk $100 \mathrm{Mesh}$. 


\section{Hasil analisi Mikrostruktur Magnet Bonded NdFeB denganmenggunakan Scanning Electron Microscope ( SEM).}

Hasil pengambilan dengan SEM ditunjukkan pada gambar

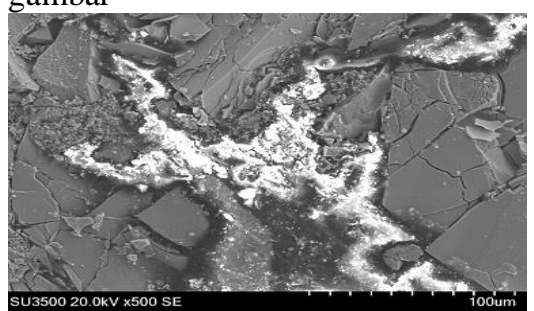

3.3a.ukuran $2,5 \%$ bakelit suhu $160^{\circ} \mathrm{C}$ dapat dilihat bahwa magnet semakin padat dari ukuran 2,5\% b akelit dan 5\% bakelit, tampak distribusi (penyebaran) bakelit semakin dekat kemunkinan karena bertambahnya komposisi bakelit dan pori pori magnet semakin kecil sepertinya hampir tidak kelihatan atau kemungkinan ditutupi oleh bakelit yang meleleh

Analisa komposisi EDX di posisi bakelit.

Pada gambar di bawah ini ditunjukkan bahwa posisi bakelit ada pada spektrum 3 yang ditandai dengan warna biru (gbr 3.4a) materal-material yang terkandung pada bakelit ditunjukkan pada gbr 3.4b.

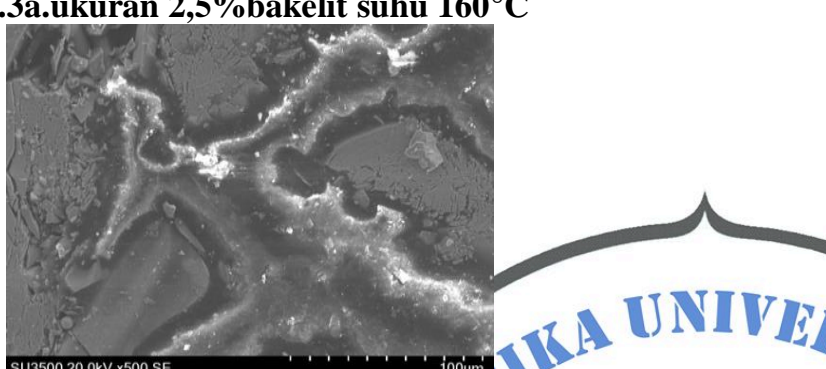

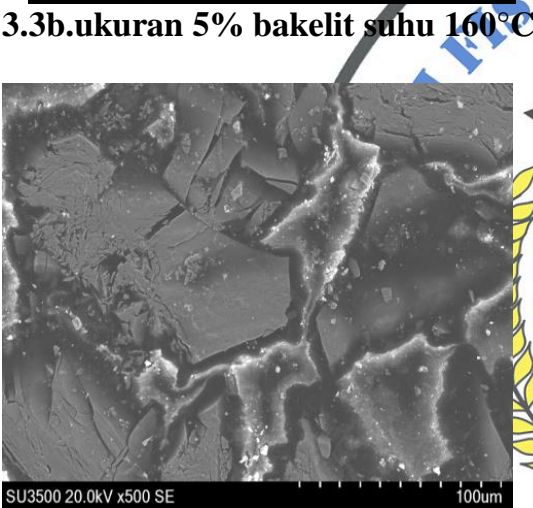

3.3c. ukuran $7,5 \%$ bakelit suhu $160^{\circ} \mathrm{C}$ perbesaran $500 \mathrm{SE}$

Berdasarkan analisis mikrostruktur dengan perbesaran 250xSE (Secondary electron = elektron sekunder) pada gambar 3.3a dapat dilihat bahwa serbuk $\mathrm{NdFeB}$ memiliki ukuran butir (grain size) yang tidak sama (seragam) dimana ukuran butir berkisar antara $2,5 \mu \mathrm{m}$ sampai $50 \mu$ m.kemudian tampak dari foto SEM distribusi (penyebaran) bakelit tidak merata dan dan setiap bakelit yang meleleh berada di antara pori-pori (rongga) magnet $\mathrm{NdFeB}$

Analisis mikrostruktur ukuran $5 \%$ bakelit dengan perbesaran 100x SE (Secondary electron = elektron sekunder) pada gambar 3.3b dapat dilihat bahwa magnet semakin padat lebih pada dari ukuran 2,5\% bakelit, tampak distribusi (penyebaran) bakelit semakin dekat kemunkinan karena bertambahnya komposisi bakelit dan pori pori magnet semakin kecil sepertinya hampir tidak kelihatan atau kemungkinan ditutupi oleh bakelit yang meleleh.

Analisis mikrostruktur ukuran 7,5 \% bakelit dengan perbesaran 100x SE (Secondary electron $=$ elektron sekunder) pada gambar $4.5 \mathrm{a}$

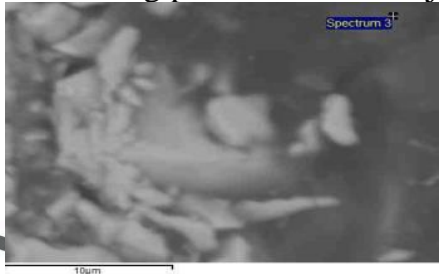

Analisa komposisi grain NdFeB dengan EDX

4 Setelah kita ketahui material-material yang ada pada bakelit,maka kita perlu juga memperhatikan menganalisa komposisi grain NdFeB dengan menggunakan EDX dengan memperhatikan gambar yang di samping ini (gambar $3.5 \mathrm{a}, 3.5 \mathrm{~b}$ dan $3.5 \mathrm{c}$
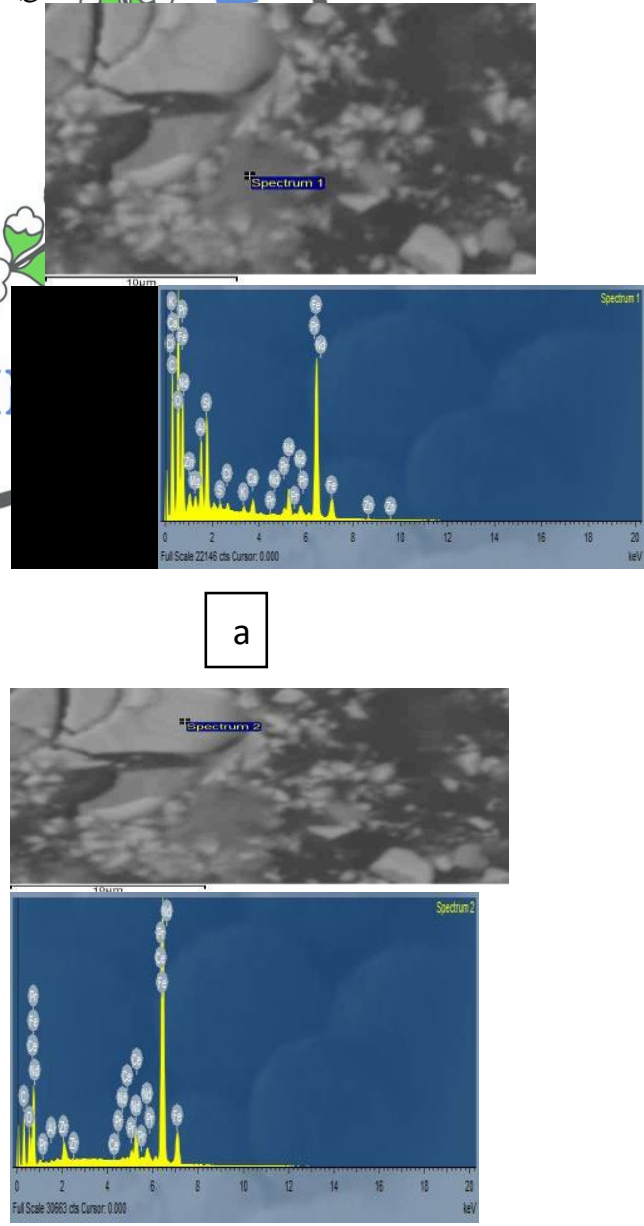

b 

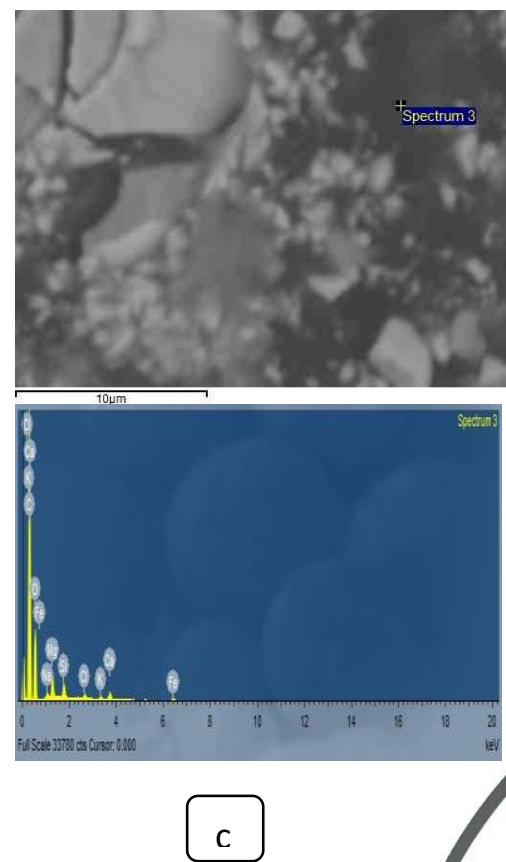

Pengujian Kuat Magnet menggựakan Permeagraph.

Karakterisasi sifat bahan NdFeBdurperoleh dari data alat Permeagraph diperoleh nilai Remanansi (Br),Koersivitas (Hc) dant Energi Produk Maksimum (BH) Gamba 4.4a Hasil karakterisasi sifât magne gampel ukuran $2,5 \%$ bakelit suhu $160^{\circ} \mathrm{C}$
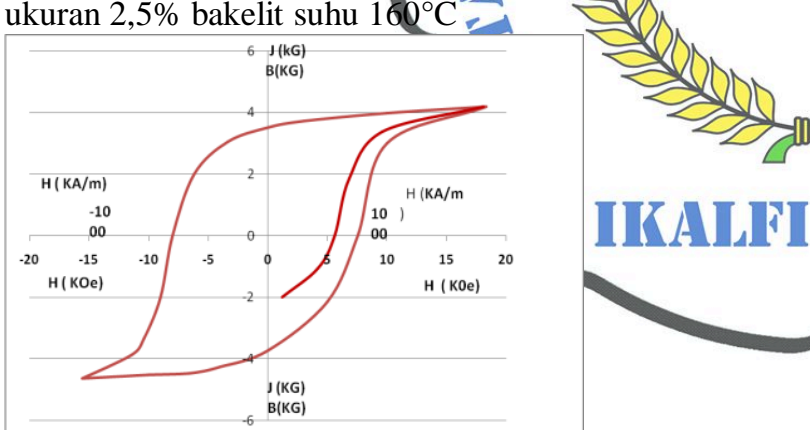
3. Sifat magnet bahan bonded $\mathrm{NdFeB}$ yang IXA.1 UN terbaik terdapat pada komposisi $2,5 \%$ suhu $160^{\circ} \mathrm{C}$ dengan dengan Bulk Densitas $\rho=$ $5,11{\mathrm{~g} / \mathrm{cm}^{3}}^{3}$, kuat magnet $=1.633 \mathrm{G} ; \mathrm{Br}=$ $3,72 \mathrm{kG} ; \mathrm{Hci}=7.557 \mathrm{KOe}$ dan $(\mathrm{BH})_{\max }=$ 2,85 MGOe

Tabel 4.3 Nilai dari (Br, Hic dan BHmax) dari bonded magnet $\mathrm{NdFeB}$ dengan variasi komposisi bakelit $2,5 \%, \% \%$ dan $7,5 \%$ (\%wt)

\begin{tabular}{cccc}
\hline $\begin{array}{c}\text { Kuat Medan } \\
\text { Magnet }\end{array}$ & Remanensi & Koersivitas & $\begin{array}{c}\text { Energi Produk } \\
\text { Maksium }\end{array}$ \\
\hline $\mathrm{B}(\mathrm{G})$ & $\mathrm{Br}(\mathrm{KG})$ & Hc ( Koe $)$ & BH (MGOe) \\
1633 & 3,72 & 7.557 & 2,85 \\
1583 & 3,65 & 7.432 & 2,58 \\
\hline 1478 & 3,14 & 7.015 & 2,02 \\
\hline
\end{tabular}

KESIMPULAN

Dari hasil penelitian/dapat disimpulkan bahwa :

1. Suhu pencetakan (hot press) bahan magnet $\mathrm{NaFeB}$ terhadap sifat fisis (densitas) mikrostruktur dan sifat kemagnetan terdaparspada suhu $160{ }^{\circ} \mathrm{C}$ pada ukuran 100 Mesh dan $140^{\circ} \mathrm{C}$ pada $200 \mathrm{Mesh}$

2. Komposisin bakelit terhadap sifat fisis (densitas) mikrostruktur dan sifat kemagnetan terdapa pada -ukuran 100 Mesh pada komposisi $2,5 \% ; 5 \%$ dan $7,5 \% \quad 160^{\circ} \mathrm{C}$ sehingga untuk mencari sifat magnet tidak perlu ukuran serbuk yang lebih kecil lagi.

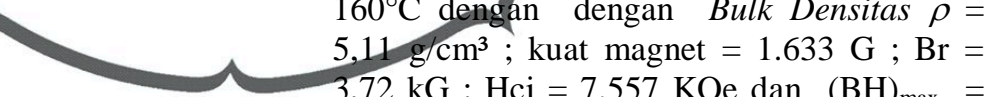

Gamba 4.4b Hasil karakterisasi sifat magnet sampel ukuran $5 \%$ bakelit suhu $160^{\circ} \mathrm{C}$
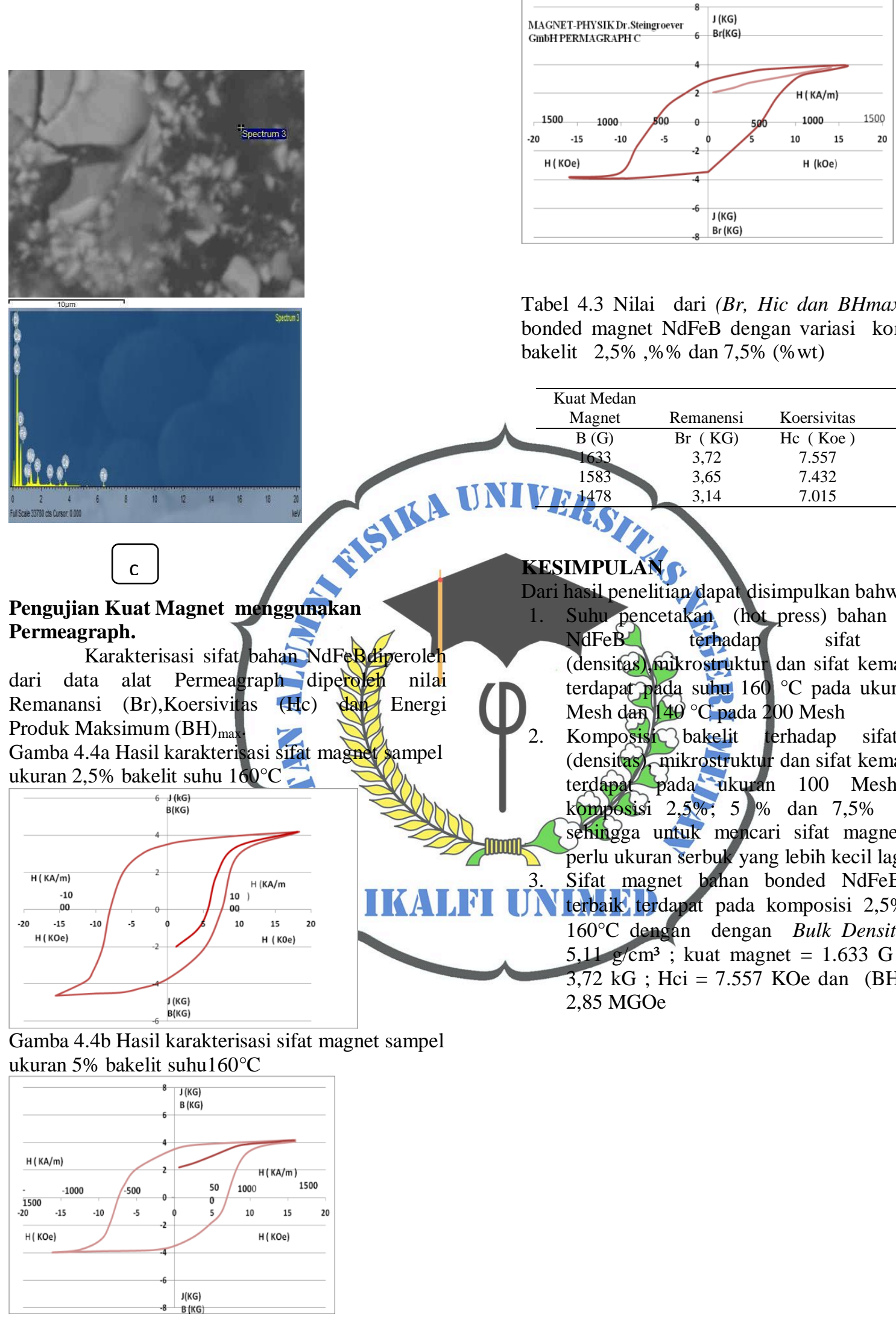


\section{DAFTAR PUSTAKA}

1. Afza,Erini.2011.Pembuatan Magnet

Permanen Ba-Hexa Ferrite

(BaO.6fe2o3)Dengan Metode

Koopresipitasi Dan

Karakterisasinya.[Skripsi].Medan :

Universitas Sumatera Utara.Program

Sarjana.

2. Djapri,Sriati.2011.Ilmu dan Teknologi

Bahan(Ilmu logam dan bukan logam)

Karakterisasinya.Penerbit Erlangga

Utara.Program Sarjana.

3. Groover.P.Mikell.2010.Fundamentals Of Modern Manufacturing Materials,Processes and System.Fourth Edition.

4. Halliday \& Resnick 1989.Fisika.Jakarta:Erlangga.

5. Muljadi dkk.2014.Mechanical Magnetic Properties of Bonded Magnet $\mathrm{NdFeB}$ produced using Bakelit.Teknologi Ind

6. Li,Ying.Kim,Y.B wang, Liñshán.Suhr,D,S Kim,K,T.Kim,OC.2000.The influence of the power particle size on the anisotropic properties of magnets by single stage hot deformation (hot Press).Journal Magnetism and Magneticnaterials

7. Perigo,E,A.de Campos,F,M.fania,N,R wandgraf,G,J,F.20 12.The Effects of the Pressing On The Microstruktur andaging of $\mathrm{N}$ dFeB bondec Magnet,Sistem Integrado Bes Biblioteca Universi De Sao Paulo
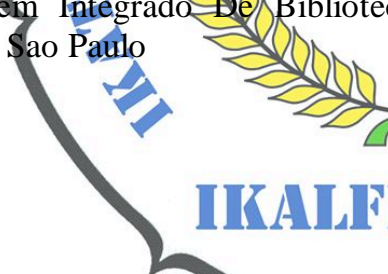

\section{IKALFI UNIMED)}

